\title{
Changing picture of energy generation in Australia and the United States
}

\author{
Lee L. Riedinger \\ University of Tennessee, Knoxville, TN 37996, USA
}

\begin{abstract}
The energy portfolio is changing for both the United States and Australia. Both countries are rich in fossil fuel reserves and both depend on burning them as a large source of energy. Both export coal and natural gas. Both are moving to more renewable supply of energy, although with different drivers and different degrees of government leadership. The United States has a sizeable nuclear component to its energy generation portfolio, but Australia does not due to a legal prohibition. How each country meets its goals of reduced carbon emissions (official or unofficial goals) is not clear at this time.
\end{abstract}

\section{Introduction}

As has been the case for most nations on Earth, the United States and Australia have depended largely on the burning of fossil fuels for its supply of energy. In 2015, 94\% of energy supply in Australia came from fossil fuels, as shown in Fig. 1. These sources produced six quads (quadrillion BTU) of energy consumed in Australia. The

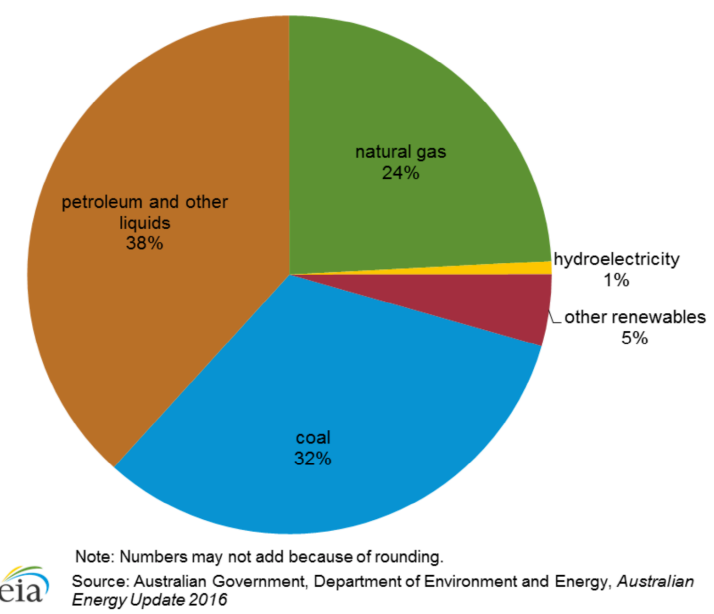

Figure 1. Primary energy consumption in Australia in 2015 [1].

U.S. dependence on fossil fuels is large but less that that in Australia, totalling $80 \%$ of energy supply and the 101 quads of energy consumed (see Fig. 2). A notable difference in these respective sources of energy is nuclear - the United States relied on nuclear energy for $8 \%$ of its 2016 energy supply (and 19\% of its generated electricity), while Australia has no nuclear power stations, by law. The two countries are different in size and population, with around 25 million people in Australia and 328 million in the United States. But, they are similar in the high per capita energy consumption, 275 million BTU for the U.S. and 222 for Australia (2013 numbers). By comparison, Germany (also a heavily industrialized country) had per capita energy consumption of 153 million BTU in 2013.
The energy mix is changing in both Australia and the United States. Natural gas has become a major source of energy supply and an increasing export item in both countries. Renewable supply of electricity is increasing in both, as the dependence on coal decreases (albeit faster in the United States than in Australia). The emission of carbon dioxide is decreasing in both countries, in Australia by federal government leadership and in the

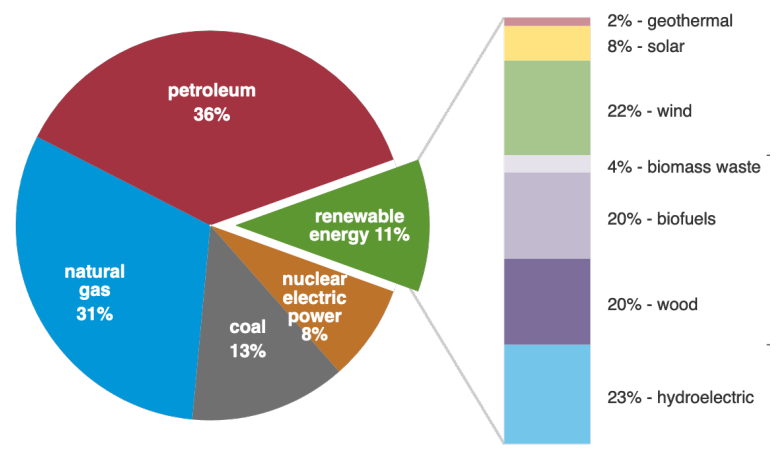

Figure 2. Energy consumption in United States in 2017 [2].

U.S. by market forces (natural gas is relatively cheap). The supply of electricity by wind and solar is increasing in both countries. Australia has committed to the greenhouse-gas reduction goals of the Paris Accords, but it is an open question how they will achieve these midcentury reduction aspirations with a currently still large dependence on burning coal and a prohibition of nuclear. The U.S. federal government has at present no commitment to the reduction goals of the Paris Accords, but over half the states have aggressive plans to increase renewables - state as opposed to federal leadership. The energy profile of both countries in mid century is difficult to predict. 


\section{Coal}

Some call the United States the Saudi Arabia of coal. Whereas Saudi Arabia has perhaps the largest proven reserves of crude oil, the United States has by far the largest known reserve of coal - roughly $28 \%$ of the world reserve (Fig. 3). Australia is also high on this world

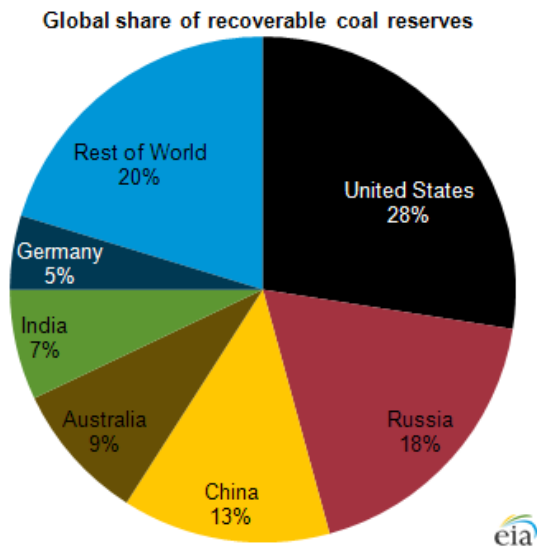

Figure 3. World coal reserves in 2011 in leading countries [3].

list, with around $9 \%$ of the world coal reserve. In a sense neither country has an energy problem. With these huge reserves of coal, the two countries could rely even more heavily on use of coal for an energy supply, e.g., converting coal to petrol for cars and heating oil for homes. But, this will not happen as the two countries have an environment and a climate change problem that is greatly worsened by increasing use of coal.

Australian coal is typically high quality with low ash content. Most of the country's coal is located in the eastern regions. Together, the states of Queensland and New South Wales accounted for nearly all of Australia's black coal (bituminous) production in 2015, and Victoria in the southeastern region accounted for $96 \%$ of brown coal (lignite and sub bituminous) production. Black coal, which accounts for a vast majority of Australia's coal production, is typically exported, and brown coal, or lignite, is used largely for domestic electricity generation. The United States has mostly bituminous coal in the east and lignite or sub bituminous in the west.

Both countries export coal, and Australia actually leads the world in amount exported (Fig. 4). Australia

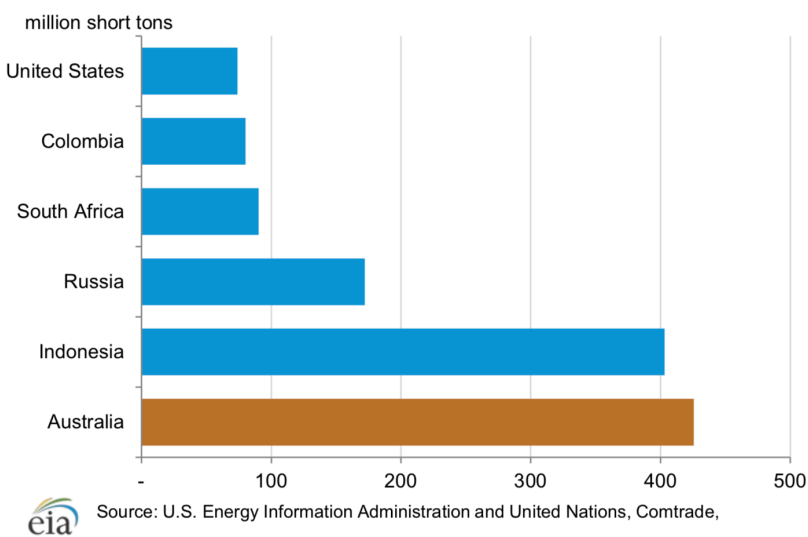

Figure 4. World's top coal exporters by weight, 2015 [1]. exports $3 / 4$ of the coal extracted from mines, and sends vast quantities of coal to Japan and China. As seen in Fig. 3 , China also has a vast reserve of coal, but not enough to satisfy its expanding economy and constantly increasing supplies of electricity required to fuel its massive manufacturing sector.

In view of the vast coal reserves in both countries, it is not surprising that both the United States and Australia have relied so heavily on coal to generate electricity over many decades.

\section{Natural gas}

A natural gas 'revolution' has occurred in the United States in the last 20 years, largely based on developing the technique to extract trapped natural gas from shale deposits in various parts of the country. Whereas some of the shale hydrocarbon reserves are rich in crude oil (e.g., the Bakkan play in North Dakota and Montana), most are richer in natural gas, e.g., the plays in Texas. Hydraulic fracturing of these shale deposits has led to an abundance of domestic natural gas and a low price, e.g., around \$2.30 per million BTU whereas this price was over six times higher at different times 10 to 15 years ago. This abundance of accessible shale gas has led to enhanced U.S. export [4] and to a clear and consistent movement away from coal to natural gas by utilities across the country, due primarily to market forces.

Australia has vast natural gas reserves that it has developed greatly in recent years. The most abundant reserves are the Greater Gorgon fields, located 80 miles off the northwest coast of Australia near Barrow Island. In 2017 Australia produced around 4 Tcf (trillion cubic feet) of natural gas and shipped around half of that to customers abroad, the largest being Japan and China. The trend of increasing availability of natural gas for export is shown in Fig. 5. In fact, Australia recently (mid 2019) overtook Qatar as the largest exporter of natural gas quite an accomplishment [5].

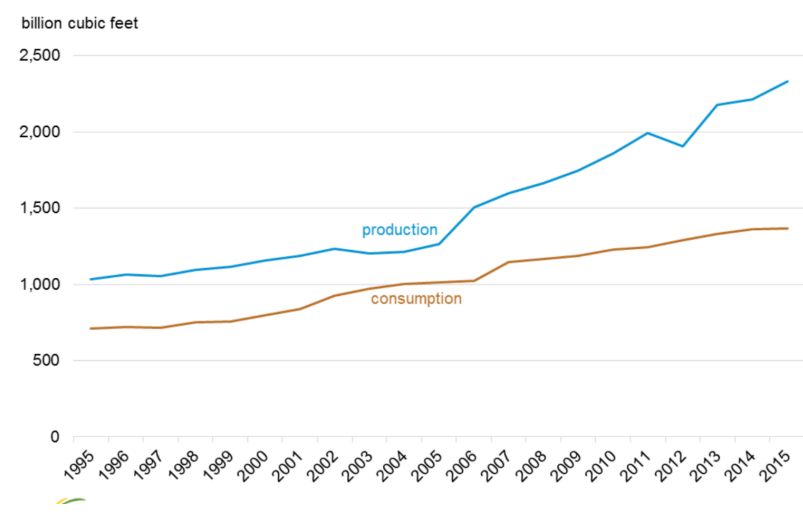

Figure 5. Australia's natural gas production and consumption, 1995 to 2015 [1].

The accessible conventional reserve of natural gas in Australia is thought be around $37 \mathrm{Tcf}$, enough to support export and domestic use for a decade. More could be extracted from shale deposits by hydraulic fracturing, but this industry has not been developed yet. The U.S. Energy Information Administration estimates that 
Australia has 429 Tcf of technically recoverable reserves, ranking the country seventh highest in the world, behind Canada, the United States, Mexico, China, Argentina, and Algeria [1]. There has been exploration for natural gas in shale deposits in the Cooper Basin in the interior of the country. However, the low cost of natural gas on the world market has slowed the country's shale gas exploration since 2014. In addition, Victoria State and Northern Territory have implemented bans on unconventional gas exploration, presumably due to environmental concerns connected with fracking.

\section{Electricity generation}

Both countries are moving away from coal as the main resource for generating electricity, even though both countries have vast reserves of coal. In the United States, a consistent move away from burning coal to using natural gas has been in process for over a decade, as the cost of natural gas has remained low. In $2018,35 \%$ of generated electricity came from natural gas compared to $27 \%$ from coal and 19\% from nuclear. This trend will persist as utilities continue to replace old coal-burning power plants with combined-cycle natural gas turbines. Between 2010 and the first quarter of 2019, U.S. power companies announced the retirement of more than 546 coal-fired power units, totalling about 102 gigawatts (GW) of generating capacity [6]. Plant owners intend to retire another $17 \mathrm{GW}$ of coal-fired capacity by 2025 . In addition, some older nuclear power plants are being closed due to the abundance of cheap natural gas.

A different picture of electricity generation in Australia for 2017 is shown in Fig. 6. The dependence

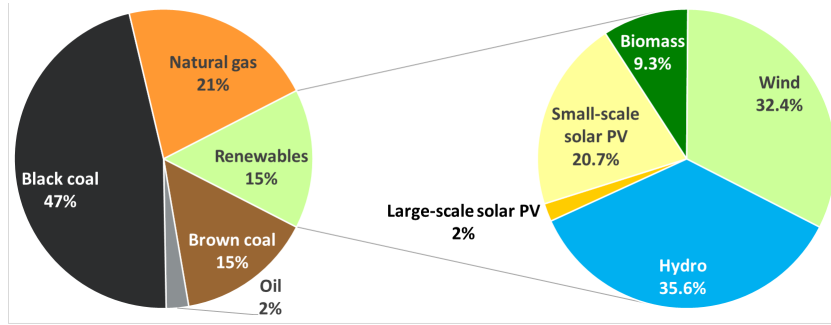

Figure 6. Australian electricity generation by type in 2017 [1].

on burning coal is high - $63 \%$ - twice as large as in the United States. Renewables are about the same in the two countries - $15 \%$ of electricity generated in Australia in 2017 and $17 \%$ for the United States in 2018. The reason for the excessive dependence on coal in Australia is the absence of nuclear, which accounted for $19 \%$ of U.S. electricity in 2018.

Australia experimented briefly with a carbon tax between 2012 and 2014, to support renewable energy programs. But, the cost of electricity to the consumer went up, the majority party in the government changed, and the carbon tax was repealed. Renewable energy is certainly increasing at present, but at a slower rate than could have been achieved with the carbon tax. In 2018 the average cost of electricity to the consumer in Australia was 33 cents AUS/kWh, which is 22 cents U.S./kWh. This is twice as high as the average cost of 10.6 cents $/ \mathrm{kWh}$ in the United States in 2018.

\section{Renewables}

Use of renewables to generate electricity is increasing in both countries, primarily wind to date. Both countries have good locations for wind speeds high enough ( 7 to 10 meters/sec) to justify the construction of farms of wind turbines. In Australia the best average wind speeds occur along the western and southern coasts and these locations have been utilized to generate around $6 \%$ of the country's electricity. In the United States, the best average wind speeds occur on the plains in the middle of the country. Figure 7 shows the location of wind turbine farms and they are clustered to a large extent in the middle of the country. Even Texas, the historical "oil

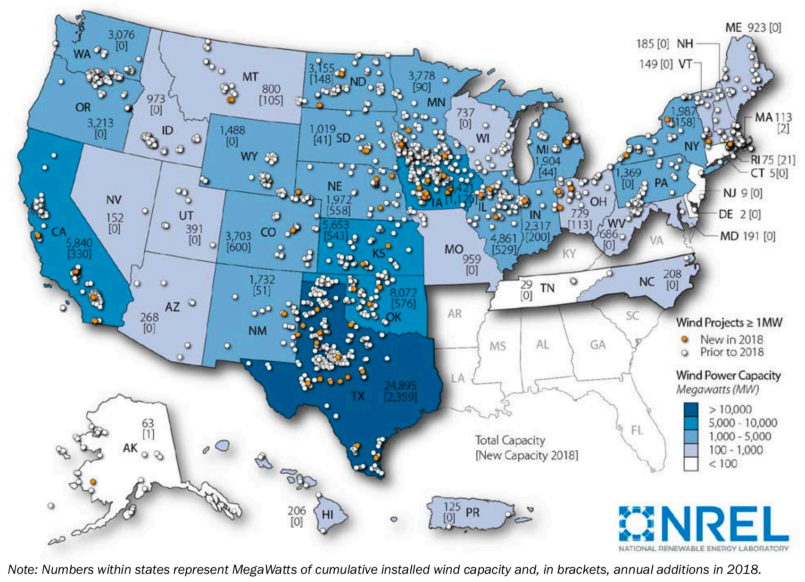

Figure 7. U.S. wind farms in 2018 [7].

state", now has the most installed wind turbines in the United States at $24 \mathrm{GW}$, and sometimes gets as much as $20 \%$ of its electricity from wind [8]. Nationally the contribution of wind to electricity generation is around $6 \%$, approaching hydro generation as the most important renewable source of electricity.

Solar-generated electricity is increasing in both countries but is still behind wind. The best place for large arrays of solar panels (photovoltaics) in Australia is in the northwest part of the country, not near the places where most people live. So far it is mostly the installation of small-scale roof-top solar PV arrays that has produced a few percent of the national electricity generation. In fact, in Queensland, residential solar panels provide at times that state's largest source of electricity, as a third of residences have solar panels installed. That is a very impressive trend. The growth of renewables in Australia is shown in Fig. 8 and illustrates a future direction for the country.

In the United States, the equivalent best location for large solar farms is the southwest. So far, the largest contributions to solar-generated power is from utilitybased projects, as opposed to residential. Solar-generated electricity is still more expensive by sometimes a factor of two compared to coal or natural gas, but the gap is narrowing especially as states adopt renewable portfolio standards that require a certain percentage of renewable generation of electricity by a certain date. A tax benefit from the U.S. federal government has spurred growth in wind and solar since its passage in the Energy Policy Act of 2005. But, this Investment Tax Credit applied to solar 


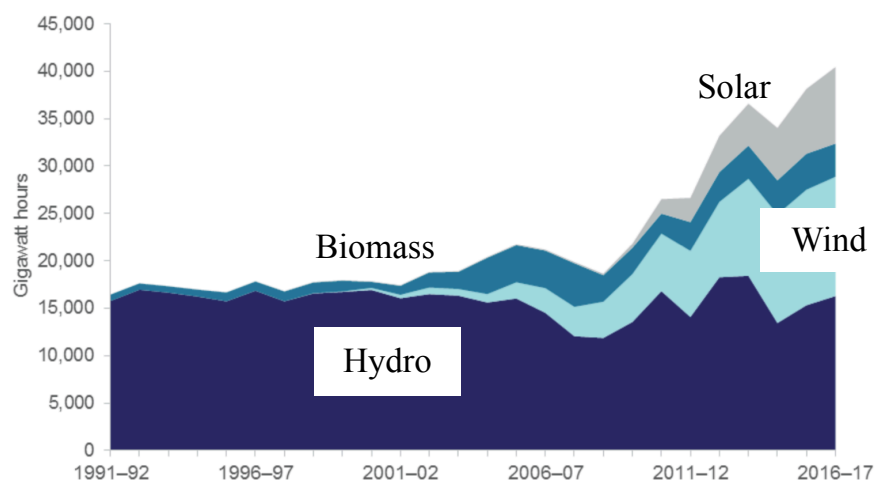

Figure 8. Australian electricity generation from renewable sources [9].

installations is due to greatly ramp down by 2023 , unless the Congress decides to renew it.

Both countries face the need for new high-voltage DC transmission lines to bring wind and solar generated electricity from the regions where these farms of devices are best built to population centres often far away. The energy agencies in both countries understand this need and have plans to address them, but finding the funds (private and/or public) to install these long-distance transmission lines will be a challenge.

Storage of variable electricity generated by wind and solar is a big problem for all countries intending to expand the role of renewables. Pumped hydro storage is a good solution, and one example is Raccoon Mountain in Tennessee. This is a $1600 \mathrm{MW}$ storage device composed of a large artificial lake on top of Raccoon Mountain as part of the Tennessee Valley Authority power complex. Water pumped up to the top of the mountain when electricity is cheap and unused at night is allowed to flow down during the day when extra power is needed. Of course, few of the United States have sufficient water and mountains to make pumped storage a common solution for storing power when wind or solar generates more than needed. Large-scale flow batteries or compressed air storage in underground caverns are more universal storage strategies, but neither is ready for wide-scale adaptation. The Australian National University Energy Change Institute has calculated that there are enough sites in Australia to make pumped hydro storage a likely common solution to the problem of storage of electrical power generated by renewable sources. It is impressive that Queensland has 10 projects to deploy $400 \mathrm{MW}$ of renewable energy generation capacity with $100 \mathrm{MW}$ of energy storage [10].

\section{$6 \mathrm{CO}_{2}$ reduction strategies}

Australia pledged in 2015 to reduce $\mathrm{CO}_{2}$ emissions to $26-28 \%$ of 2005 levels by 2030, as part of the 'Paris accord' among the nations of the world. Under this target, $23.5 \%$ of Australia's electricity will come from renewable sources by 2020 and the country is on target to achieve this by an increasing emphasis on renewables [11]. There is no agreement on the reduction target for 2050, but it would be a large reduction in emissions, more than $50 \%$, based on more wind and solar and much less use of coal. There is no agreement about how to achieve a large midcentury $\mathrm{CO}_{2}$ reduction, but states will play a role [12].

In the United States, the Obama administration accepted the Paris goals $\left(26-28 \%\right.$ reduction in $\mathrm{CO}_{2}$ emissions), but the Trump administration has not. Thus there is now no national plan for reduced emissions, but this is slowly happening anyway due to the rapid switch from coal to natural gas in power generation (due to cheap natural gas) - natural gas has half the $\mathrm{CO}_{2}$ emissions of coal. Also, wind-generated power is increasing rapidly. As a result $\mathrm{CO}_{2}$ emissions in 2019 are down by $13 \%$ compared to 2005 . Future reductions depend on economic issues and on whether federal tax incentives for renewables are extended (not likely at this time). In the absence of a federal commitment to $\mathrm{CO}_{2}$ reductions, half of the states have made their own pledge to move to increased incorporation of renewal electricity generation in coming years, as shown in Fig. 9. At least

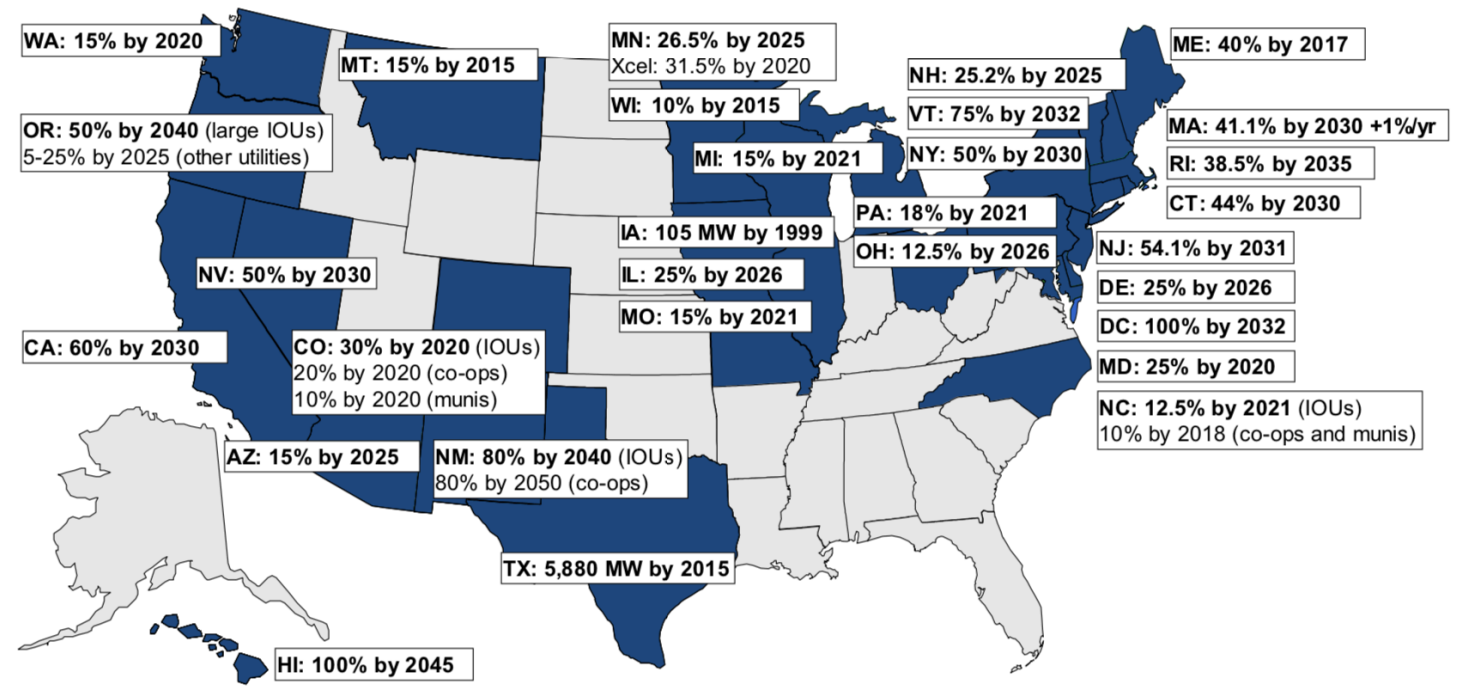

Figure 9. U.S. Renewable Portfolio Standards 2018 status [13]. 
at this time, it will be state leadership (not federal) that determines the country's response to the problems of climate change, in addition to market forces resulting from cheap natural gas.

\section{Nuclear energy}

The United States has had a large and robust baseline generation of electricity from nuclear power plants for decades. This peaked at 104 nuclear generating stations with a total of around $100 \mathrm{GW}$ of power output. This sector still provides around $19 \%$ of baseline electricity generation. But, in various ways this part of the U.S. power generation is in slow decline. Few new nuclear power plants are opening and a number are being closed. The cost of construction has continued to rise and the regulatory issues remain increasingly complex. The country has not been able to build and open a permanent repository for spent fuel rods, meant to be at Yucca Mountain in Nevada, called for by a law that Congress passed in 1983. As 40 and in some cases 60-year operating licenses expire, the country will have to find a replacement for this large baseline of rock-steady power generation. The answer is entirely unclear. Few large 1 GW nuclear power stations are likely to be built, but maybe the new idea of a fleet of Small Modular Reactors (SMR) will mature.

The situation in Australia is even more murky. A law prohibits nuclear energy, which makes it difficult to imagine a low-carbon baseline of steady power generation for the national grid. Various government panels and study groups have addressed this problem and recommended national changes. For example, nowdeceased ANU Professor George Dracoulis was a member of a national study panel in 2006 (Switkowski commission) that recommended nuclear energy be considered in Australia [14,15], but realizing that such power would be $20-50 \%$ more expensive than coal-fired power and would need a carbon tax of Aus $\$ 15-40$ per tonne to compete. The carbon tax was implemented in 2012 but repealed in 2014. Alan Finkel - Australia's Chief Scientist - has suggested nuclear power be considered for inclusion in Australia's future low-carbon energy mix [16]. Angus Taylor - Energy Minister announced a parliamentary inquiry into what would be necessary to develop a nuclear energy industry, maybe based on SMRs. A 2019 survey found that $44 \%$ of Australians support nuclear power, up four points since the last survey in 2015 [17]. An irony is that Australia has the world's largest proved recoverable reserve $(29 \%)$ of uranium ore; Australia is a major exporter. Perhaps Australia should consider a nuclear industry since the need for electrical power could double by 2050, coal needs to be largely replaced in order to further reduce $\mathrm{CO}_{2}$ emissions, and a new baseline generation to go with increasing renewable generation is needed. This is not likely to happen without a carbon tax, which was already implemented and repealed.

\section{Future}

The United States and Australia both face profound challenges in energy generation and use in coming decades. The global climate is warming as the $\mathrm{CO}_{2}$ content of the atmosphere has risen from $280 \mathrm{ppm}$ (parts per million) in the mid 1800 s to $410 \mathrm{ppm}$ in 2019 . The average global temperature has risen by around $1{ }^{\circ} \mathrm{C}$ over that period. The hope has been that the world could take action, drastically reducing $\mathrm{CO}_{2}$ emissions to keep the atmospheric content to not more than $450 \mathrm{ppm}$ by mid century. But, this is a very big world challenge that is unlikely to be met.

Leadership by the United States on how to combat or adapt to an increasingly warmer climate is needed but unlikely to consistently happen. The specific energyrelated challenges to the United States are the following.

- Will the United States repair or replace the nuclear component? This will be difficult and perhaps unlikely.

- Can the U.S. maintain the rapid growth of wind (and solar) with the federal tax credits phasing out? This is unlikely, although there will still be a market drive in this direction at least in a reduced form.

- Can the United Stares accelerate the move to electric vehicles to move away from petroleum? To accomplish this, a federal government push is necessary but unlikely.

- Can the United States achieve 30\% renewable generation of electricity by 2050 ? This might happen based on state leadership but not federal programs.

- Can fracking continue to keep natural gas cheap and crude oil more abundant? This seems likely to happen.

- Will the United States take climate change seriously? This is slowly happening but will take years to evolve and states to lead the way.

Australia is similar to the United States in many ways related to energy. And, the questions for the future are just as profound. But, tentative answers to these questions are far beyond the scope of this article.

- Can Australia really move so aggressively away from coal, technically and politically? This seems like a huge challenge.

- Will electrical energy storage be sufficient for Australia (and the world) to have mostly renewable energy by mid century? This is a huge question that cannot be answered at this time.

- Is the Australian electrical grid robust enough to handle a large renewable energy input?

- Will the government adopt a Clean Energy Target to guide the future?

- Can Australia meet reduced carbon emission goals with no nuclear component? This question will continue to be debated and argued among very smart and informed people in the country.

Both countries will need to adapt to an increasingly warm climate. Rather than limiting the $\mathrm{CO}_{2}$ content to $450 \mathrm{ppm}$ by mid century, a more likely scenario is 700 ppm by the end of the century and another 1.5 to $2{ }^{\circ} \mathrm{C}$ increase. Agriculture will need to shift, on average, to higher latitudes and ocean levels will rise by perhaps half a meter. Of course, these changes will be slow and humans will adapt to these changes. But, along the way, the United States and Australia, as similar coal-rich countries, will have to find their respective ways to an 
energy-generation portfolio almost completely devoid of coal.

\section{References}

[1] U.S. Energy Information Administration, Country Analysis Brief: Australia, updated March 7, 2017.

[2] U.S. Energy Information Administration, U.S. energy facts explained.

[3] U.S. Energy Information Administration, United States leads world in coal reserves, September 2, 2011.

[4] Forbes, Australia, U.S. LNG Exports Turn Up The Volume On Global Market Leader Qatar, August 28, 2019.

[5] U.S. Energy Information Administration, Australia is on track to become world's largest LNG exporter, August 12, 2019.

[6] U.S. Energy Information Administration, More U.S. coal-fired power plants are decommissioning as retirements continue, July 26, 2019.

[7] National Renewable Energy Laboratory, 2018 Wind Report.

[8] U.S. Energy Information Administration, Texas ranks first in U.S.-installed wind capacity and number of turbines, July 31, 2019.

[9] Australian Energy Update 2018.

[10] Energy Storage News, Queensland picks 'top 10 shortlist' for 400MW renewables, 100MW energy storage auction, July 24, 2019.

[11] Mike Brown, Inverse, Clean Energy: Why Australia Is About to Beat Its Renewable Energy Target, September 4, 2019.

[12] The Guardian, Clean energy target: how the states might make it work, July 13, 2017.

[13] Galen Barbose, Lawrence Berkeley National Laboratory, U.S. Renewable Portfolio Standards 2018 Annual Status Report, November 2018.

[14] World Nuclear News, Taskforce supports consideration of nuclear, January 12, 2007.

[15] Sydney Morning Herald, Switkowski to head nuclear inquiry, June 7, 2006.

[16] The Guardian, Forget coal wars, says Alan Finkellook at emission outcomes, October 13, 2018.

[17] The Guardian, Australians' support for nuclear plants rising - but most don't want to live near one, June 17, 2019. 